\title{
The Earrings of God
}

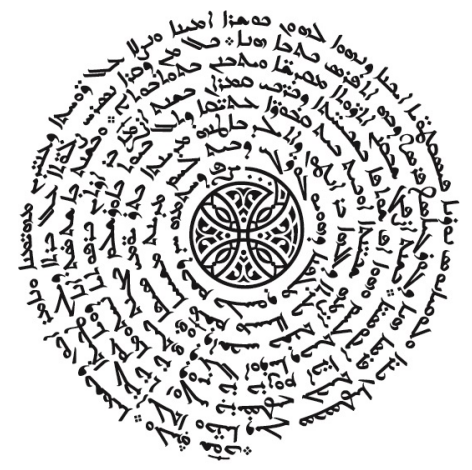




\section{Perspectives on Philosophy and Religious Thought}

Perspectives on Philosophy and Religious Thought (formerly Gorgias Studies in Philosophy and Theology) provides a forum for original scholarship on theological and philosophical issues, promoting dialogue between the wide-ranging fields of religious and logical thought. This series includes studies on both the interaction between different theistic or philosophical traditions and their development in historical perspective. 


\section{The Earrings of God}

The absurd among us

\section{By \\ Fortunato Pasqualino}

Translated and Annotated by

Gabriel Lahood

Gorgias

2021 
Gorgias Press LLC, 954 River Road, Piscataway, NJ, 08854, USA

www.gorgiaspress.com

2021 Copyright (C) by Gorgias Press LLC

All rights reserved under International and Pan-American Copyright Conventions. No part of this publication may be reproduced, stored in a retrieval system or transmitted in any form or by any means, electronic, mechanical, photocopying, recording, scanning or otherwise without the prior written permission of Gorgias Press LLC.

2021

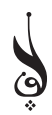

ISBN 978-1-4632-4359-3

ISSN 1940-0020

\section{Library of Congress Cataloging-in-Publication} Data

A Cataloging-in-Publication Record is available at the Library of Congress.

Printed in the United States of America 